\title{
Physiological and Morphological Identification of Somatostatin- or Vasoactive Intestinal Polypeptide-Containing Cells among GABAergic Cell Subtypes in Rat Frontal Cortex
}

\author{
Yasuo Kawaguchi and Yoshiyuki Kubota \\ Laboratory for Neural Circuils, Bio-Mimetic Control Research Center, The Institute of Physical and Chemical Research \\ (RIKEN), Nagoya 456, Japan
}

Physiological and morphological characteristics of GABAergic nonpyramidal cells in frontal cortex of young rats identified immunohistochemically as containing somatostatin or vasoactive intestinal polypeptide (VIP) were studied in vitro by whole-cell recording and biocytin injection. We have found that most somatostatin- or VIP-containing neurons were different from two other types of GABAergic cells, the parvalbumin-containing fast-spiking cells and the latespiking cells (neurogliaform cells). In response to injected currents, somatostatin- or VIP-containing nonpyramidal cells showed either bursts of a few spikes on a slow-depolarizing hump, burst-spiking nonpyramidal cells, or single spikes only on depolarization, regular-spiking nonpyramidal cells. Morphologically, both somatostatin- and VIP-containing cells had vertical axonal arbors terminating in symmetrical synapses that were immunoreactive for GABA in electron micrographs. Somatostatin cells included neurons with main ascending axons sending collaterals into layer I (Martinotti cells in deep layers). Some of the Martinotti cells in layer $V$ also contained calbindin $D_{28 k}$. VIP cells included neurons the main descending axons of which had more descending than ascending collaterals (bipolar cells and double bouquet cells). Two other morphological forms of the VIP cells were those with short descending axons with collaterals bearing multiple boutons on other cell bodies (small basket cells) or with short ascending main axons with collaterals forming arcades (arcade cells). Some of these neurons also contained calretinin. From these results, it appears that the GABAergic neurons controlling circuits in the neocortical layers may be characterized further based on whether they contain somatostatin or VIP.

Key words: nonpyramidal cell; neocortex; frontal cortex; somatostatin; vasoactive intestinal polypeptide; calbindin $D_{28 k}$; calretinin; parvalbumin; double bouquet cell; Martinotti cell; small basket cell; arcade cell; fast-spiking cell; neurogliaform cell; GABA
Neocortical output neurons, the pyramidal cells, are organized in laminae depending on their projection sites. GABAergic interneurons, all of which are nompyramidal cells, are considered to regulate the activity of these laminar structures through inhibition (Somogyi, 1989; White, 1989; Jones, 1993). Many kinds of neuropeptides and calcium-binding proteins have been shown to be expressed by neocortical cells. This chemical heterogeneity is much more distinct among nonpyramidal cells than pyramidal cells (DeFelipe, 1993; Jones, 1993). In addition, nonpyramidal cells are characterized by a diversity of morphological forms (Jones, 1975; Fairén et al., 1984; Somogyi, 1989; Ramón y Cajal, 1995). However, the morphologies of chemically defined subclasses of nonpyramidal cells have been well identified in only a few cases (DeFelipe, 1993).

To understand better the possible functional role of a particular neocortical cell, it is necessary to examine more than chemical and morphological characteristics. For example, information concerning intrinsic firing patterns can be important in distinguishing belween subpopulations of neurons (Connors and Gutnick, 1990; Kawaguchi and Kubota, 1995). Pyramidal cells can be divided into

\footnotetext{
Received Aug. 7, 1995; revised Dec. 26, 1995; accepted Jan. 16, 1996.

This work was supported by the Frontier Research Program. We thank Edward G. Jones, Raymond Kado, and Christopher N. Honda for discussions and comments on this manuscript, and we thank Naoko Wada for technical assistance.

Correspondence should be addressed to Yasuo Kawaguchi, Laboratory for Neural Circuits, RIKEN, 3-8-31 Rokuban, Atsuta, Nagoya 456, Japan.

Copyright $\odot 1996$ Society for Neuroscience $0270-6474 / 96 / 162701-15 \$ 05.00 / 0$
}

two subtypes based on differences in the firing patterns in response to threshold stimuli (McCormick et al., 1985; Agmon and Connors, 1989; Mason and Larkman, 1990). Recently, it has been revealed that nonpyramidal cells can also be divided into several physiological subtypes based on firing patterns in response to depolarizing pulses (Foehring et al., 1991; Kawaguchi, 1993, 1995; Deuchars and Thomson, 1995). These physiological subgroups may correlate with chemical or morphological subgroups. Cells immunoreactive for the calcium-binding protein parvalbumin (Celio, 1986) belong to one physiological subtype of nonpyramidal cells, the fast-spiking (FS) cells. These cells have axonal arborizations that are dense near their somata and extended, including extended plexus cells (Fairén et al., 1984), and a few branches of some parvalbumin FS cells make multiple boutons on the perikarya (Kawaguchi and Kubota, 1993; Kawaguchi, 1995). Identification of other nonpyramidal cells with different chemical markers by morphological characteristics and physiological firing patterns may be a useful tool to elucidate cellular interactions in neocortical local circuits.

Immunoreactivity for neuropeptides is also mostly detected in GABAergic nonpyramidal cells (Hendry et al., 1984b; Somogyi et al., 1984; Rogers, 1992; DeFelipe, 1993). Among the peptides in neocortex, somatostatin and vasoactive intestinal polypeptide (VIP) are expressed in separate populations of GABAergic cells (Demeulemeester et al., 1988; Rogers, 1992; Kubota et al., 1994). These peptides may be differentially expressed among morphological subtypes of nonpyramidal cells. Bipolar cells are immuno- 


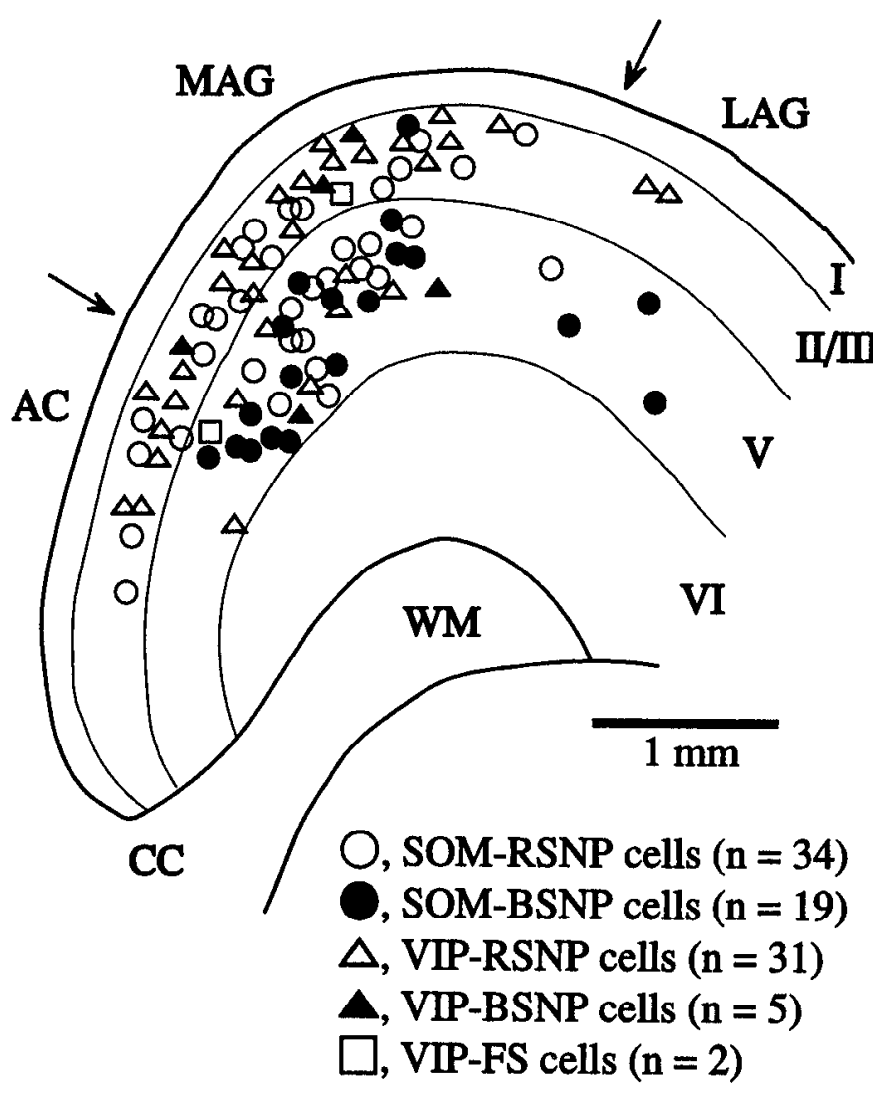

Figure 1. A composite drawing of distribution of somatostatin- or VIPimmunoreactive nonpyramidal cells sampled from oblique horizontal slices of rat frontal cortex. SOM, Somatostatin; VIP, vasoactive intestinal polypeptide; $R S N P$, regular-spiking nonpyramidal; $B S N P$, burst-spiking nonpyramidal; $F S$, fast-spiking; $A C$, anterior cingulatc cortcx; $C C$, corpus callosum; $L A G$, lateral agranular cortex; $M A G$, medial agranular cortex; $W M$, white matter. Roman numerals correspond to cortical layers.

histochemically labeled with antibody to VIP, but not to somatostatin (Connor and Peters, 1984; Mizukawa et al., 1987; Hajós et al., 1988a). Both somatostatin- and VIP-immunoreactive terminals form synapses with dendritic shafts and spines. In addition, there are VIP-positive axon terminals around the somata of pyramidal cells (Hajós et al., 1988b; De Lima and Morrison, 1989; Peters 1990). These data suggest that somatostatin cells and VIP cells may have different functional roles within the neocortical circuit. In the present study, the physiological and morphological properties of somatostatin- and VIP-containing cells were investigated in neocortex.

\section{MATERIALS AND METHODS}

Slice preparation and whole-cell recording. Sections of rat frontal cortex (200- $\mu \mathrm{m}$-thick; $18-22 \mathrm{~d}$ postnatal) were cut in a plane oblique to horizontal (Kawaguchi, 1992) and put into a solution (in $\mathrm{mM}$ : $\mathrm{NaCl} 124.0, \mathrm{KCl}$ 3.0, $\mathrm{CaCl}_{2} 2.4, \mathrm{MgCl}_{2}$ 1.2, $\mathrm{NaHCO}_{3} 26.0, \mathrm{NaH}_{2} \mathrm{PO}_{4}$ 1.0, glucose 10.0) bubbled with a mixture of $95 \% \mathrm{O}_{2} / 5 \% \mathrm{CO}_{2}$. Cells were recorded from frontal cortex (Fig. 1) in a whole-cell current-clamp mode at $29-30^{\circ} \mathrm{C}$ using a $40 \times$ water immersion objective (Kawaguchi, 1993, 1995). Electrode solution consisted of the following (in $\mathrm{mM}$ ): $\mathrm{K}$-methylsulfate 120 , EGTA $0.6, \mathrm{MgCl}_{2} 2.0$, ATP 4.0, GTP 0.3, HLPES 10 , and biocytin 20. Recordings were made by conventional bridge-balance and capacitance neutralization techniques using intracellular amplifier (Axoclamp-2B, Axon Instruments, Foster City, CA). Resting potentials were measured just after the patched membranes were ruptured by suction. Input resistances of cells were determined by passing hyperpolarizing current pulses (duration, $500-600 \mathrm{msec}$ ) inducing voltage shifts of $6-15 \mathrm{mV}$ negative to rest. Spike threshold and spike-widths at half-amplitude were measured for spikes elicited by depolarizing current pulses (duration, $50 \mathrm{msec}$ ) of threshold strength. Generation of two or more spikes on slow humps from hyperpolarization (burst-spiking) was investigated by depolarizing current pulses of threshold strength from -75 to $-85 \mathrm{mV}$.

Fluorescence immunohistochemistry for somatostatin and VIP. The slices were fixed with $4 \%$ paraformaldehyde and $0.2 \%$ picric acid overnight at $4{ }^{\circ} \mathrm{C}$, followed by incubation in phosphatc buffer (PB) containing $10 \%$ sucrose for $30 \mathrm{~min}$ and $20 \%$ sucrose for $1 \mathrm{hr}$. The tissue was then frozen with dry ice and thawed three times. The slices were incubated in PB containing $0.5 \% \mathrm{H}_{2} \mathrm{O}_{2}$ for $30 \mathrm{~min}$ to suppress endogenous peroxidase activity. The slices were then incubated overnight at room temperature with rat monoclonal antibody against somatostatin (diluted 1:500; Chemicon, Temecula, CA) and rabbit antiserum against VIP (1:1000; Incstar, Stillwater, MN), followed by incubation in a mixture of dichlorotriazinyl-aminofluorescence-dihydrochloride (DTAF) anti-rat IgG (1:100; Chemicon), 7-amino-4-methylcoumarin-3acetic acid (AMCA) anti-rabbit IgG (1:100; Chemicon) for $4 \mathrm{hr}$, and Texas Red-avidin (1:2000; Amersham, Arlington Heights, IL) for $3 \mathrm{hr}$. Crossreactivity of the secondary antibodies was not observed. After fluorescence observations, the slices were reacted with avidin-biotin-peroxidase complex and 3,3'-diaminobenzidine tetrahydrochloride (DAB). The dendrites, axonal processes, and somata of DAB-labeled neurons were drawn using a camera lucida.

Fluorescence immunohistochemistry for calbindin $D_{28 k}$ or calretinin. After fixation, freeze thawing, and reaction with $\mathrm{H}_{2} \mathrm{O}_{2}$ as above, the slices were incubated in a mixture containing a rat monoclonal antibody against somatostatin (Chemicon), and rabbit antiserum against calbindin $D_{28 k}$ (1:1000; from Dr. Emson, The Babraham Institute, Cambridge, UK) or rabbit antiserum against calretinin (1:1000; Swant, Bellinzona, Switzerland). After washing, the slices were incubated with DTAF-conjugated anti-rat IgG, AMCA-conjugated anti-rabbit IgG, and Texas Redconjugated streptavidin. After fluorescence observation, the slices were reacted with avidin-biotin-peroxidase complex and DAB. The dendrites, axonal processes, and somata of DAB-labeled neurons were drawn using a camera lucida.

Postembedding GABA immunohistochemistry for ultrathin sections. After fixation with $4 \%$ paraformaldehyde, $2.5 \%$ glutaraldehyde, and $0.2 \%$ picric acid overnight at $4^{\circ} \mathrm{C}$, the slices were incubated in PB containing $10 \%$ sucrose for $1 \mathrm{hr}$ and $20 \%$ sucrose for $3 \mathrm{hr}$, followed by freeze thawing twice using liquid nitrogen. The slices were incubated in PB containing $1 \%$ sodium borohydrate for $30 \mathrm{~min}$ and in Tris-buffered saline (TBS) containing $1 \% \mathrm{H}_{2} \mathrm{O}_{2}$ for $30 \mathrm{~min}$. The slices were then incubated with avidin-biotin-peroxidase complex in TBS containing $0.05 \%$ Triton X-100 (TX) overnight at $4^{\circ} \mathrm{C}$, stained with $\mathrm{DAB}$, osmicated, dehydrated, and embedded in Epon. After camera lucida reconstruction, stained cells were serially sectioned with an ultramicrotome. Ultrathin sections on nickel mesh grid were washed with TBS containing $0.1 \%$ TX (TBST) and incubated with antiserum for GABA (1:5000; Sigma, St. Louis, MO) in TBST overnight at $20^{\circ} \mathrm{C}$. The ultrathin sections were incubated with colloidal gold-conjugated anti-rabbit IgG (1:100; BioCell, Cardiff, UK) in TBST (Phend et al., 1992; Buhl et al., 1994) and stained with 1\% uranyl acetate and lead citrate. No immunoreaction was observed in the ultrathin sections incubated in antiserum for GABA that had been preabsorbed with an excess of GABA antigen $(0.1 \mathrm{~mm})$.

Video images of intracellularly stained cells were captured using a $20 \times$ objective lens with a Sony XC-7500 CCD camera. The somatic areas and diameters in the long and short axes were measured using computerbased image analysis (National Institutes of Health Image).

Slice shrinkage after fixation. After fixation, dehydration, and embedding, slices had shrunk to $\sim 80 \%$ in area $[82 \pm 4 \%(n=4)$ in slices fixed by $4 \%$ paraformaldehyde and $0.2 \%$ picric acid, and $81 \pm 2 \%(n=5)$ in slices fixed with $4 \%$ paraformaldehyde, $2.5 \%$ glutaraldehyde, and $0.2 \%$ picric acid]. Data are given as mean \pm SD. For statistical analysis in comparing cell classes, the Mann-Whitney $U$ test was used.

\section{RESULTS}

\section{Physiological identification of neuropeptide cells}

Cells in layers $\mathrm{II} / \mathrm{III}$ and $\mathrm{V}$ with resting potentials more negative than $-45 \mathrm{mV}$ and overshooting spikes were sampled by whole-cell current-clamp recording in medial agranular, anterior cingulate, and lateral agranular cortex (Fig. 1). Morphologically identified nonpyramidal cells stained with biocytin in layers II/III and V were divided into four physiological classes by their firing patterns in response to depolarizing current pulses in a manner modified 


\section{$\operatorname{SOM}(+), \operatorname{VIP}(-)$}
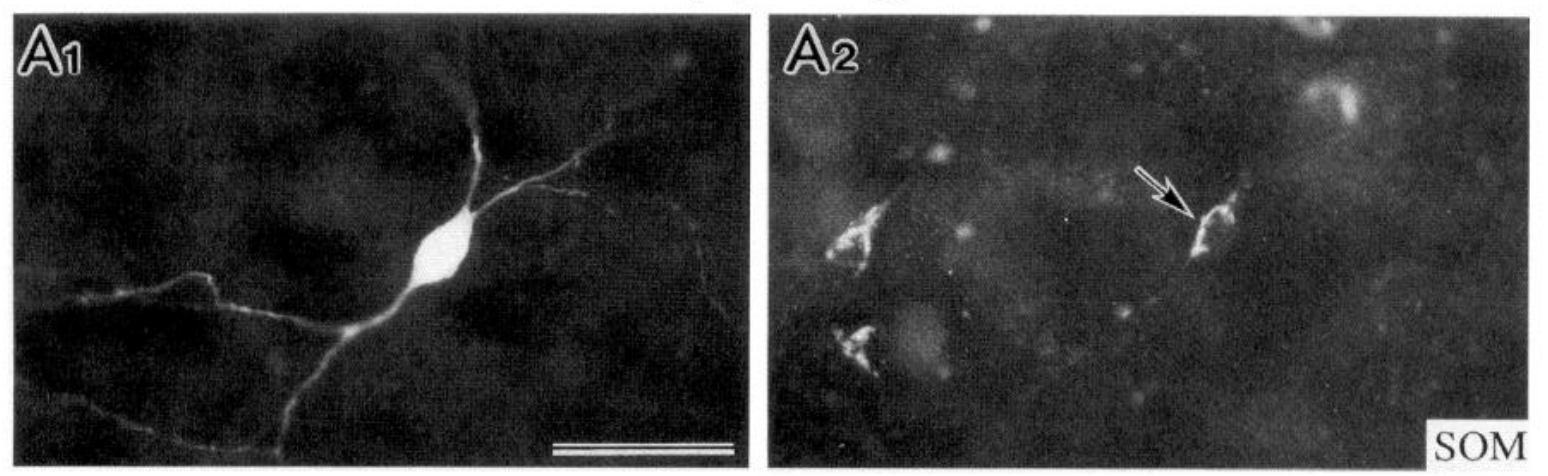

\section{B1}
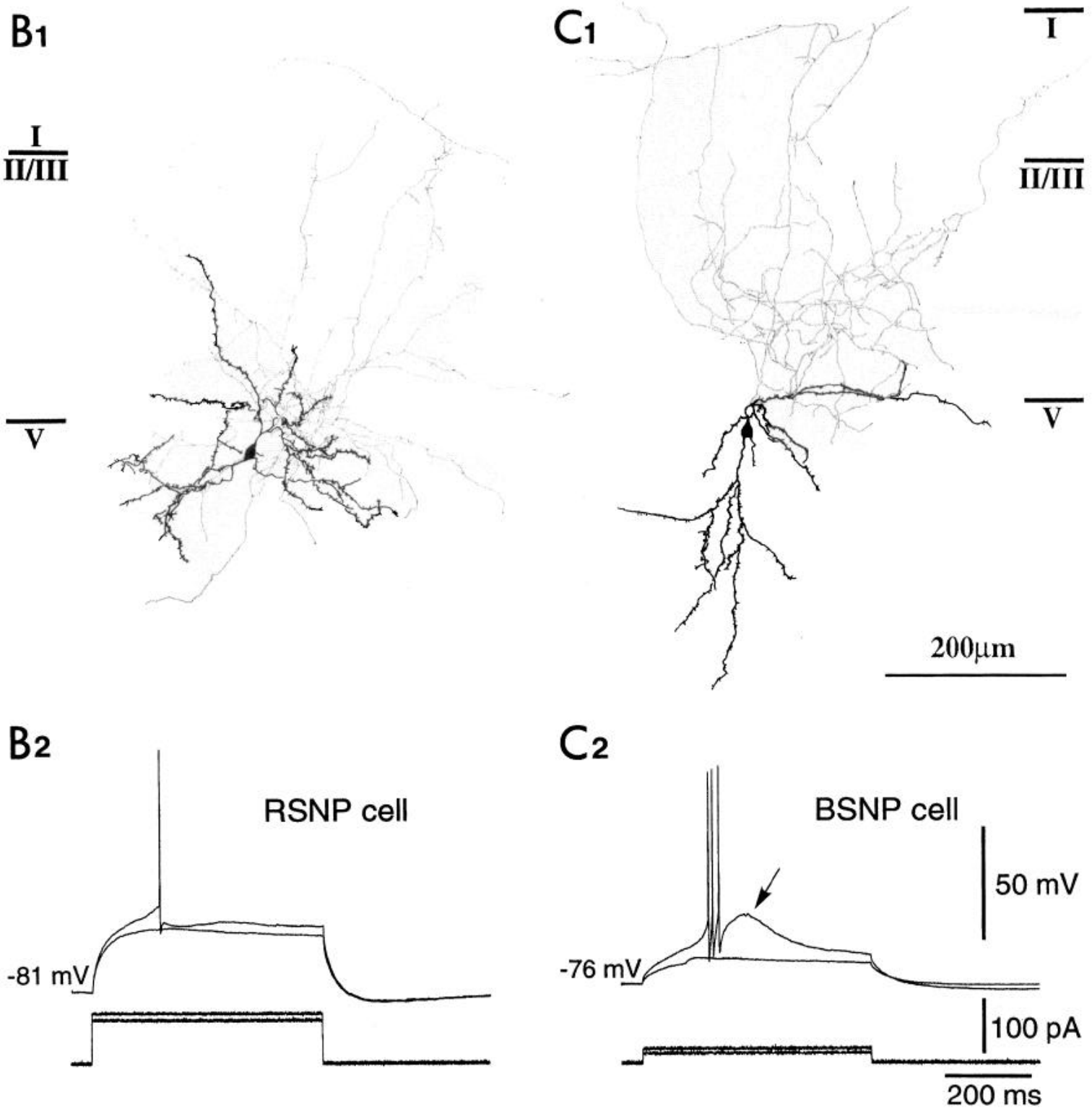

Figure 2. Morphologies of cells identified as somatostatin (SOM)-positive and their recorded activities. The somata and dendrites are shown in black, and the axons in gray. A1, A biocytin-injected cell. Scale bar, $50 \mu \mathrm{m}$. $A 2$, Somatostatin immunoreactivity in the same section as $A 1$. An identified cell was positive for somatostatin (arrow) and negative for VIP (not shown). B, The morphology and firing pattern of a somatostatin RSNP cell. B1, Note the ascending axonal branches going up to layer I. This was a Martinotti cell in layer V. B2, The cell in B1 was regular-spiking in response (top trace) to injected current pulses (bottom trace) from the potentials hyperpolarized by continuous currents. Resting membrane potential, $-65 \mathrm{mV}$. Note single spike at a threshold stimulus. Note also the absence of FS characteristics, ramp depolarization, and burst-spiking on slow depolarizing hump in RSNP cells. $C$, The morphology and firing pattern of a somatostatin BSNP cell. C1, Note the axonal branches going up to layer I, as in $B 1$. This was also a Martinotti cell in layer V. C2, Burst-spiking of the cell in $C 1$, induced by depolarizing current pulses (bottom trace) from the potentials hyperpolarized by continuous currents. Resting membrane potential, $-65 \mathrm{mV}$. Note the bursting activity of regular spikes on an LTS (arrow). 

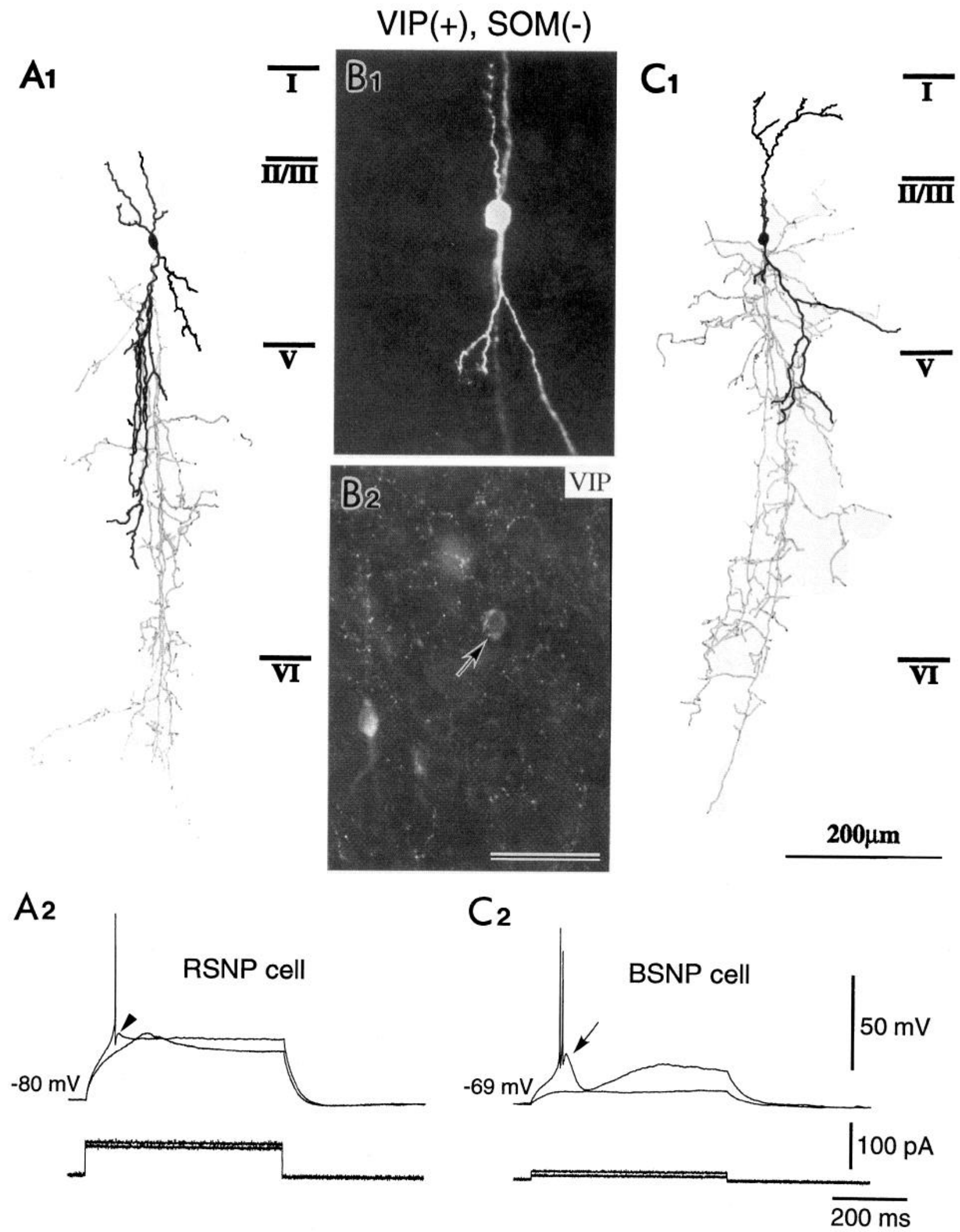

Figure 3. Morphologies and electrical activities of VIP cells. $A$, The morphology and firing pattern of a VIP RSNP cell. Al, Note the descending axonal branches and bitufted dendrites. This was a double bouquet cell. A2, Activity of the cell in A1 evoked by depolarizing current pulses (bottom trace) when hyperpolarized to $-80 \mathrm{mV}$ by continuous currents. Resting membrane potential, $-69 \mathrm{mV}$. Note a regenerative hump produced by the depolarization by a weaker current that did not trigger a spike, and also a single spike on a depolarizing hump (arrowhead) at threshold. B1, A biocytin-injected cell. B2, VIP immunoreactivity in the same section as B1. An identified cell was positive for VIP (arrow) and negative for somatostatin (not shown). Scale bar, $50 \mu \mathrm{m}$. $C$, The morphology and firing pattern of a VIP BSNP cell-the same cell as in $B . C 1$, Note the descending axonal branches, as in $A 1$. This was also a double bouquet cell. $C 2$, The same cell had a resting potential of $-69 \mathrm{mV}$ and produced two spikes on a depolarizing hump from hyperpolarized potentials by continuous currents, which were followed by a marked hyperpolarization. 
Table 1. Properties of immunohistochemically identified nonpyramidal cells in rat frontal cortex

Nonpyramidal cells immunoreactive for:

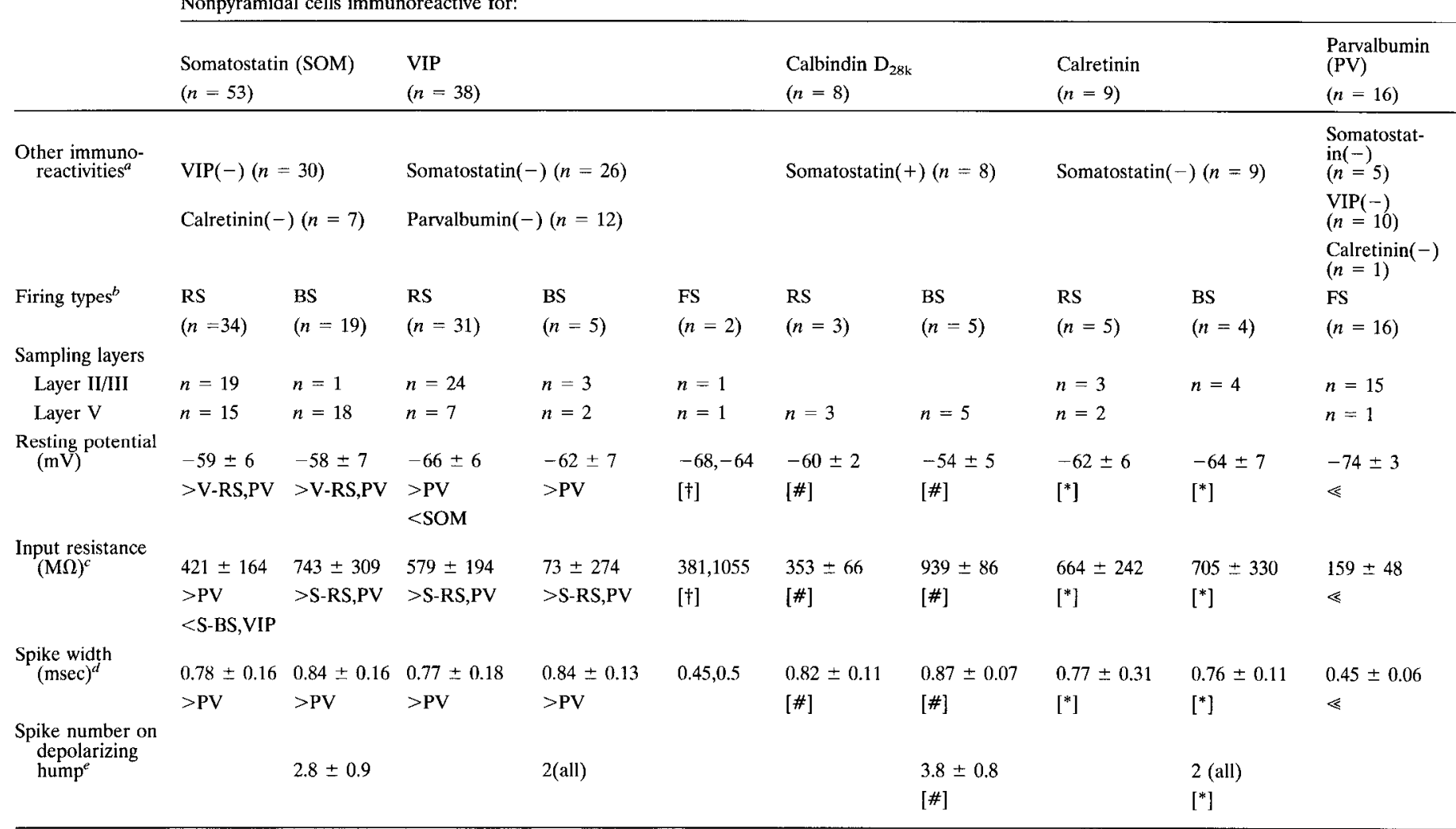

Data are mean \pm SD. $n$, Number of cells.

${ }^{a}(+)$, Positive; $(-)$, negative. Parvalbumin immunoreactivity was not detected in RSNP, BSNP, and LS cells (Kawaguchi and Kubota, 1993; Kawaguchi, 1995). Somatostatin $(n=11)$ and VIP $(n=7)$ immunoreactivities were not detected in LS cells.

${ }^{b}$ RS, Regular-spiking; BS, burst-spiking; FS, fast-spiking; LS, late-spiking.

' Input resistance was determined by hyperpolarizing current pulses inducing voltage shift of 6-15 $\mathrm{mV}$ negative to rest.

${ }^{d}$ At half-amplitude.

${ }^{e}$ Number of spikes arising on depolarizing humps from hyperpolarized potentials in BSNP cells.

[†] Two VIP FS cells had more positive resting potentials and larger input resistances than PV FS cells.

[\#] These electrophysiological parameters of calbindin $D_{28 \mathrm{k}}$ RSNP and BSNP cells were not significantly different from somatostatin RSNP and BSNP cells, respectively.

$\left[{ }^{*}\right]$ These electrophysiological parameters of calretinin RSNP and BSNP cells were not significantly different from VIP RSNP and BSNP cells, respectively.

$>$ A, $<$ B, Significantly larger than that of A cells and smaller than that of B cells, respectively $(p \leq 0.01)$.

$\ll$, Significantly smaller than that of the other types of cells.

S-RS, Somatostatin RSNP cells; S-BS, somatostatin BSNP cells; V-RS, VIP RSNP cells.

Table 2. Morphological properties of somatostatin- and VIP-immunoreactive nonpyramidal cells in rat frontal cortex

Somatostatin cells $\quad$ VIP cells

$(n=39) \quad(n=31)$

\begin{tabular}{lllll}
\hline $\begin{array}{l}\text { Morphological } \\
\text { types }\end{array}$ & $\begin{array}{l}\text { asc main axon, asc }>\text { dsc }^{*} \\
(n=39) \\
\text { Martinotti cell }\end{array}$ & $\begin{array}{c}(1) \text { dsc main axon, dsc }>\text { asc* } \\
(n=24) \\
\text { bipolar cell, double bouquet cell }\end{array}$ & $\begin{array}{c}\text { (2)small basket cell } \\
(n=2)\end{array}$ & $\begin{array}{c}(3) \text { arcade cell } \\
(n=5)\end{array}$ \\
$\begin{array}{l}\text { Sampling layers } \\
\quad \text { Layer II/III }\end{array}$ & $\begin{array}{l}n=15 \\
n=24\end{array}$ & $\begin{array}{l}n=19 \\
n=5\end{array}$ & $n=2$ & $n=2$ \\
$\quad$ Layer V & $144 \pm 29(76-218)$ & $118 \pm 27(81-199)$ & $110(97,123)$ & $n=3$ \\
Somatic area $\left(\mu \mathrm{m}^{2}\right)$ & & & $107 \pm 10(92-119)$ \\
Somatic diameter & $16.8 \pm 3.0(12.2-26.1)$ & $14.8 \pm 2.7(10.7-22.2)$ & $12.9(11.9,13.8)$ & $15.4 \pm 1.2(14.6-17.2)$ \\
$\quad$ Long axis $(\mu \mathrm{m})$ & $11.0 \pm 1.6(7.9-15.0)$ & $10.2 \pm 1.1(8.4-12.0)$ & $10.9(10.4,11.3)$ & $8.8 \pm 0.7(8.1-9.9)$
\end{tabular}

$n$, Number of cells. Data are mean \pm SD. Ranges are in parentheses. Cross-sectional somatic areas and diameters were measured.

${ }^{*}$ asc, Ascending; dsc, descending; asc $>d s c$, more ascending than descending branches; $d s c>$ asc, more descending than ascending branches. 
A

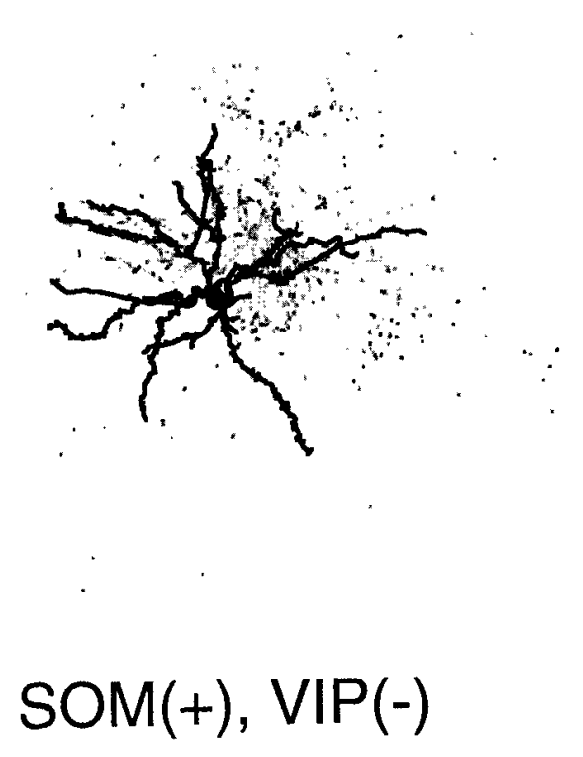

Figure 4. A, A layer II/III somatostatin (SOM) cell. This was an RSNP cell and was negative for VIP. Note that somatostatin cells in layer II/III also had mainly ascending collaterals to layer I. $B$, A layer $V$ VIP cell. This was an RSNP cell and was negative for somatostatin and a bipolar cell. Note that VIP in layer V cells also has mainly descending axonal branches into layer VI. The somata and dendrites are shown in black, and the axons in gray.

\section{B}
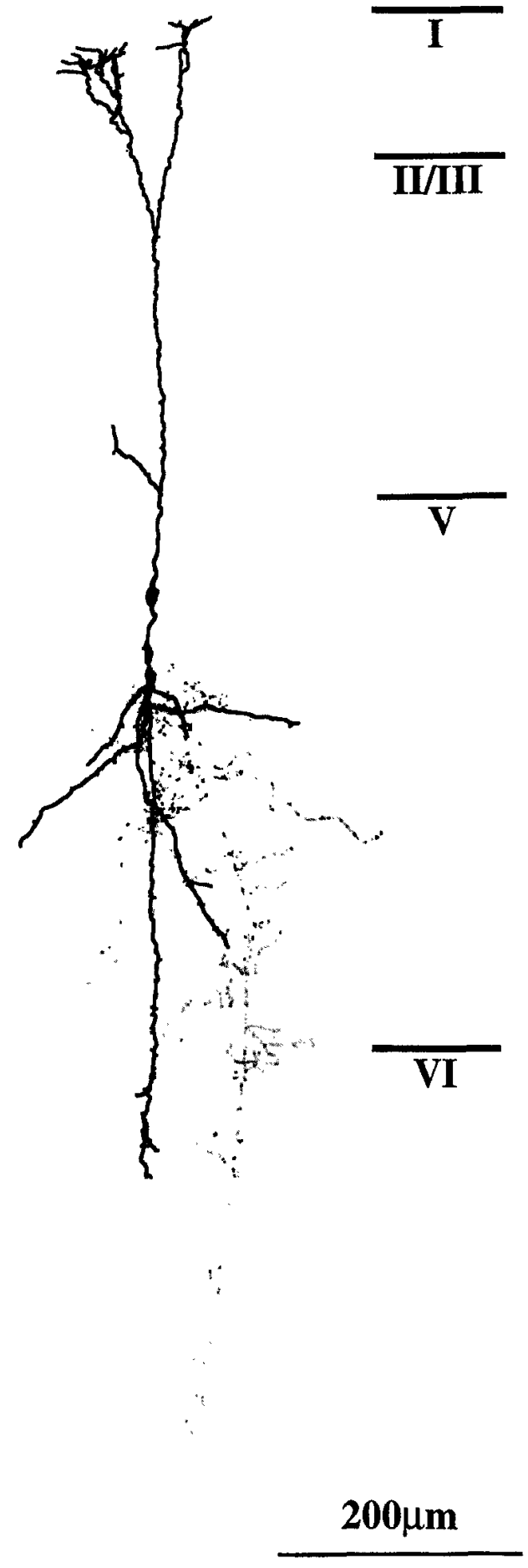

VIP(+), SOM(-) from previous physiological studies on layer II/III (Kawaguchi, 1995) and layer V (Kawaguchi, 1993). (1) FS cells had lower input resistances than other types of cells and showed abrupt episodes of nonadapting repetitive discharges of short-duration action potentials. (2) Late-spiking (LS) cells exhibited slowly developing ramp depolarizations to near threshold. (3) Burst-spiking nonpyramidal (BSNP) cells fired two or more spikes on slow depolar- izing humps from hyperpolarized potentials. Low-threshold spikes (LTS) of longer duration were induced in some BSNP cells, especially in layer V (LTS cells: Kawaguchi, 1993). (4) Regularspiking nonpyramidal (RSNP) cells could not be categorized into the above three subgroups. In some RSNP cells, depolarizing pulses from a hyperpolarized state induced a depolarizing hump with single spike. 
We investigated the physiological and morphological characteristics of 53 somatostatin-immunoreactive cells (Fig. 2A) and 38 VIP-immunoreactive cells (Fig. $3 B$ ) (Table 1). Immunofluorescent reactions for these peptides were scattered patchily in the somata (Mizukawa et al., 1987; Rogers, 1992). Nonpyramidal cells showing both somatostatin and VIP immunoreactivity were not encountered in this study. Most identified nonpyramidal cells with somatostatin or VIP immunoreactivity belonged to the groups of BSNP cells or RSNP cells. Parvalbumin-immunoreactive cells were FS cells $(n=16)$ with lower input resistances and more negative resting potentials than other chemical classes of nonpyramidal cells (Table 1) and were negative for somatostatin or VIP. Neither of the neuropeptides was detected in LS cells $(n=18 ; 11$ cells negative for somatostatin, 7 cells negative for VIP).

\section{Somatostatin-containing Martinotti cells}

Somatostatin cells included RSNP cells (Fig. 2B2) and BSNP cells (Fig. 2C2). Somatostatin RSNP cells were found in both layers II/III and V, but somatostatin BSNP cells were all mostly in layer $\mathrm{V}$ except one (Table 1, Fig. 1). Most of layer $\mathrm{V}$ somatostatin BSNP cells exhibited longer-duration LTS (Fig. 2C2). The number of spikes arising on the depolarizing hump in BSNP cells ranged from 2 to 5. One somatostatin RSNP cell in layer $V$ showed a depolarizing hump with a single spike from hyperpolarized potentials. Somatostatin cells had longerduration action potentials, higher input resistances, and less negative resting membrane potentials than parvalbumin cells. Somatostatin BSNP cells had higher input resistances than somatostatin RSNP cells.

Among identified somatostatin cells, we found 25 RSNP cells ( $n=14$ in layer II/III and $n=11$ in layer V) and 14 BSNP cells (layer $\mathrm{V}$ ) with axons that were stained sufficiently to classify the cells according to the axonal branching and distribution patterns. Soma diameter of recorded cells was smaller than $20 \mu \mathrm{m}$ in most cases and larger than $20 \mu \mathrm{m}$ in 4 cells (Table 2). The dendrites were multipolar or bitufted. The axonal arbors of both RSNP (Fig. 2B1) and BSNP somatostatin cells (Fig. 2C1) had common characteristics. A main axon originated either from the soma or from a dendrite, then ascended and emitted radiating collaterals with obliquely upward, horizontal, or obliquely downward orientations. In five cells, main axons appeared from the white matter side, but soon changed their direction and ascended up to layer I. About one-half of the collaterals from main ascending axons were upward or obliquely upward in direction, onequarter were horizontal, and the remaining one-quarter were descending or obliquely descending. Although many axon collaterals are cut off because of the nature of thin slice preparation, horizontal collaterals could be traced further than $200 \mu \mathrm{m}$ from the somata in horizontal direction. In 6 cells, horizontal spread from the somata ranged from 300 to $600 \mu \mathrm{m}$. The main axon and some ascending collaterals entered layer I and ramified, or formed horizontal collaterals. Both layer V (Fig. 2) and layer II/III (Fig. $4 A$ ) somatostatin cells had ascending main axons with more ascending collateral arbors. Thus, somatostatin cells include nonpyramidal cells with mainly ascending axonal arbors, and Martinotti cells in deep layers (Fairén et al., 1984; Wahle, 1993).

\section{VIP-containing bipolar cells and double bouquet cells}

VIP cells also mostly belonged to RSNP (Fig. 3A2) and BSNP types (Fig. 3C2). VIP RSNP cells were found in both layers II/III and V, as were VIP BSNP cells (Table 1). The number of spikes arising on depolarizing humps in BSNP cells was 2 in all 5 cases.
Eleven VIP RSNP cells showed depolarizing humps with a single spike from hyperpolarized potentials (Fig. $3 A 2$ ). The resting potential, input resistance, and spike width at half-amplitude were similar in both VIP RSNP and VIP BSNP cells (Table 1). VIP cells had less negative resting membrane potentials, higher input resistances, and longer-duration action potentials than parvalbumin cells. VIP RSNP cells had more negative resting potentials than somatostatin cells. VIP cells had higher input resistances than somatostatin RSNP cells. Among 38 VIP cells, 2 showed abrupt repetitive firing of spikes of short duration and were classified as FS cells, but these VIP cells showed higher input resistances than common FS cells containing parvalbumin (Table 1). These two cells showed the most common morphological characteristics of VIP cells, namely, descending axonal arbors (see below).

Among identified VIP cells, we found $25 \operatorname{RSNP}(n=20$ in layer II/III; $n=5$ in layer V) cells, 4 BSNP cells ( $n=2$ in layer II/III; $n=2$ in layer $\mathrm{V}$ ), and 2 FS cells ( $n=1$ in layer II/III; $n=1$ in layer $\mathrm{V}$ ) with local axons that were stained sufficiently to morphologically classify the cells according to the distribution patterns of axonal branching that were not uniform. The cells had bitufted, bipolar, or multipolar dendrites. Soma diameter of recorded cells was smaller than $20 \mu \mathrm{m}$ in all cases except one (Table 2). The most characteristic form ( $n=24 ; 19$ RSNP cells, 3 BSNP cells, and 2 FS cells) was a long descending main axon originating either at the soma or from a dendrite, which emitted axon collaterals (Figs. 3A1,C1, $4 B$ ). About one-half of the collaterals from main descending axons were downward or obliquely downward in direction, one-quarter were horizontal, and the remaining onequarter were ascending or obliquely ascending. In most cells of this type, the horizontal extent of the axonal arbors from somata was within $200 \mu \mathrm{m}$. Horizontal axonal spread of this type of VIP cells was more limited than that of somatostatin cells. However, axonal arbors in 2 VIP cells with descending main axons extended to $300-500 \mu \mathrm{m}$ from the somata (Fig. $5 A$ ). One of these two had a soma diameter larger than $20 \mu \mathrm{m}$. Side branches from the descending collaterals, in some cases, made grape-like terminal knobs. In some VIP cells, a few descending collaterals formed axonal bundles (Fig. 3). In summary, the present results confirm that VIP cells have descending axonal arbors (Hajós et al., 1988a; Peters, 1990), including bitufted cells with descending arbors (double bouquet cells) (Valverde, 1978; Fairén et al., 1984; Somogyi and Cowey, 1984; DeFelipe et al., 1990) and bipolar cells with narrow descending arbors (bipolar cells) (Peters, 1984).

\section{VIP-containing small basket cells and arcade cells}

Although most VIP cells had descending axonal arbors, we found other morphological forms $(n=7)$ with bitufted or multipolar dendrites. Among them, 2 RSNP cells had short descending main axons originating from the soma, which emitted axonal arbors. Some of their branches made multiple axonal contacts preferentially on cell bodies and proximal dendrites of other cells (Fig. $5 B$ ). From the innervation patterns, these VIP cells are considered to include small basket cells (Fairén et al., 1984; Peters, 1990).

In the remaining 4 RSNP VIP cells ( $n=2$ in layer II/III, and $n=2$ in layer $\mathrm{V}$ ) and 1 BSNP VIP cell in layer $\mathrm{V}$, a short ascending main axon originated either from the soma or from a proximal dendrite within or just above the dendritic field and broke up into collaterals (Fig. $5 C$ ). The main axon and collaterals emitted branches that descended into the dendritic field, forming axonal arcades. These cells are considered to correspond to arcade cells (Jones, 1975; Peters and Saint Marie, 1984). Some of 


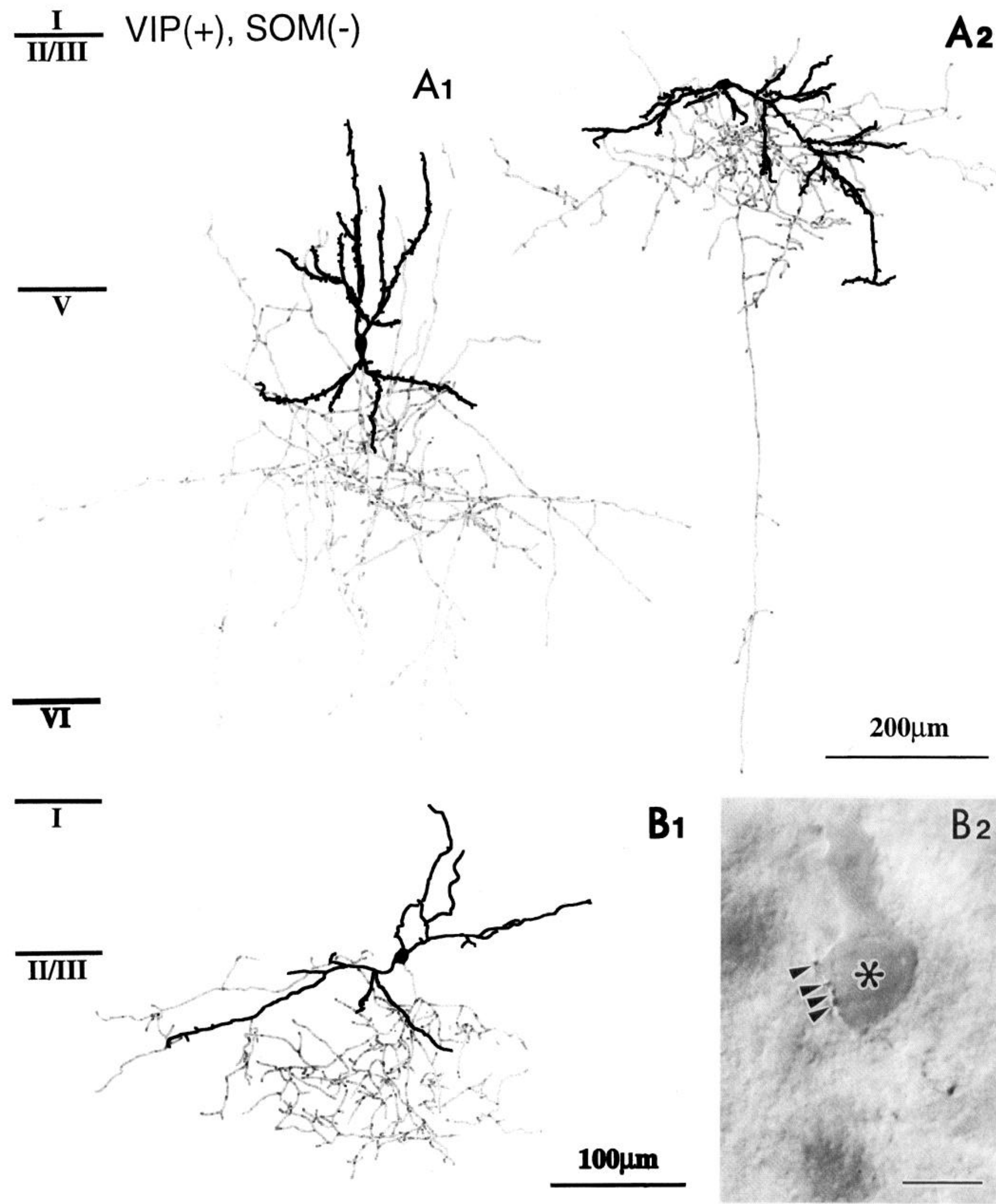

Figure 5. A, VIP cells with descending main axons and wide horizontal innervation. A1, A VIP cell in layer V. This cell belonged to RSNP cells. A2, A VIP cell in layer II/III. This cell belonged to RSNP cells. $B$, A VIP-positive small basket cell with collaterals making multiple boutons on other cell bodies. $B 1$, Note a main axon descending shortly and emitting axon collaterals in layer II/III. This cell belonged to RSNP cells. B2, A photomicrograph of the terminal of the VIP cell. Note the boutons (arrowheads) surrounding an unstained cell body (asterisk). Scale bar, $20 \mu \mathrm{m}$. C, A VIP-positive arcade cell in layer V. This cell belonged to BSNP cells. Note the ascending main axon (arrowhead) breaking into descending collaterals (arrows) and making arcade patterns, like curved roofs. Figure continues. 


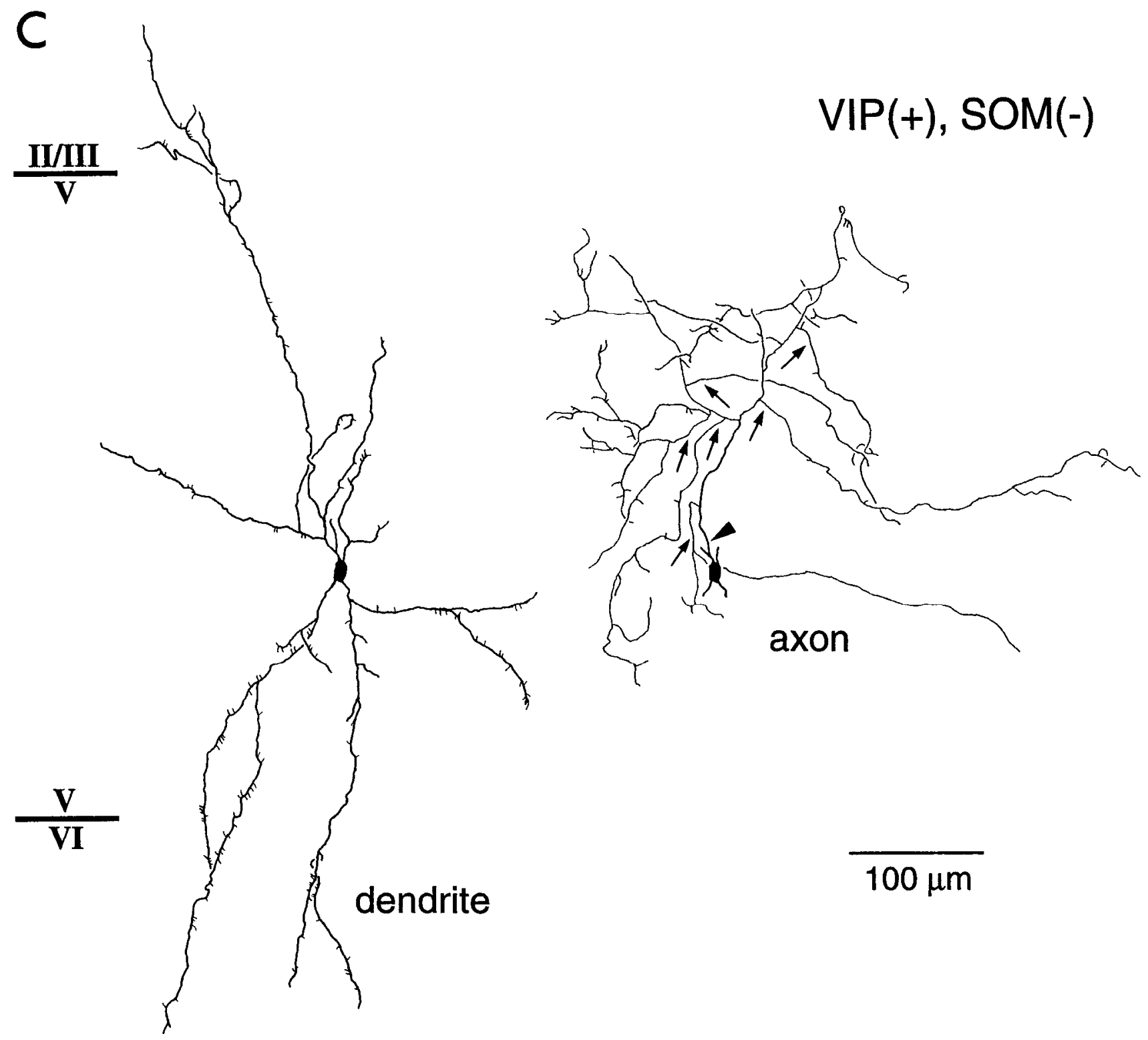

Figure 5 continued.

these axon collaterals also made multiple contacts on cell bodies and proximal dendrites of other cells.

\section{$\mathrm{Ca}^{2+}$-binding proteins in BSNP and RSNP cells}

Parvalbumin is preferentially distributed in FS cells (Kawaguchi and Kubota, 1993; Kawaguchi, 1995). In addition to parvalbumin, two other calcium-binding proteins, calbindin $\mathrm{D}_{28 \mathrm{k}}$ and calretinin, are localized mainly to nonpyramidal cells, although calbindin $D_{28 k}$ is also found in pyramidal cells of layer II/III (Demeulemeester et al., 1989; Hendry et al., 1989; DeFelipe, 1993; Kubota et al., 1994). In layer $\mathrm{V}$, nonpyramidal cells with LTS and that were immunoreactive for calbindin $\mathrm{D}_{28 \mathrm{k}}$ had ascending axonal arbors (Kawaguchi and Kubota, 1993). Because layer V somatostatin cells had ascending axonal arbors, it was investigated whether RSNP cells and BSNP cells immunoreactive for somatostatin in layer $\mathrm{V}$ were also positive for calbindin $\mathrm{D}_{28 \mathrm{k}}$ (Fig. $6 A$ ). Among 9 RSNP cells and 7 BSNP cells immunoreactive for somatostatin, 3 RSNP cells and 5 BSNP cells were also positive for calbindin $D_{28 \mathrm{k}}$, some of the axons of which were well stained and formed ascending arbors (Fig. 6B). Electro- physiological differences could not be detected between somatostatin cells positive or negative for calbindin $\mathrm{D}_{28 \mathrm{k}}$. The electrophysiological parameters of calbindin $\mathrm{D}_{28 \mathrm{k}}$ RSNP and BSNP cells were similar to somatostatin RSNP cells and BSNP cells, respectively (Table 1). This suggests that both RSNP cells and BSNP cells in layer V with ascending axonal arbors may contain both somatostatin and calbindin $\mathrm{D}_{28 \mathrm{k}}$.

Calretinin-immunoreactive cells were also sought by triplcimmunofluorescence studies for calretinin, somatostatin, and injected biocytin. Nine calretinin cells negative for somatostatin ( $n=7$ in layer II/III, and $n=2$ in layer V) (Rogers, 1992; Kubota and Kawaguchi, 1994; Kubota et al., 1994) were either RSNP cells $(n=5)$ or BSNP cells $(n=4)$. The electrophysiological parameters of calretinin RSNP and BSNP cells were similar to VIP RSNP and BSNP cells, respectively (Table 1). These included cells with descending axonal arbors (double bouquet cells and bipolar cells) ( $n=5$ ) (Fig. $6 C$ ) or small basket cells $(n=2)$. This suggests that calretinin cells have morphological and electrophys- 

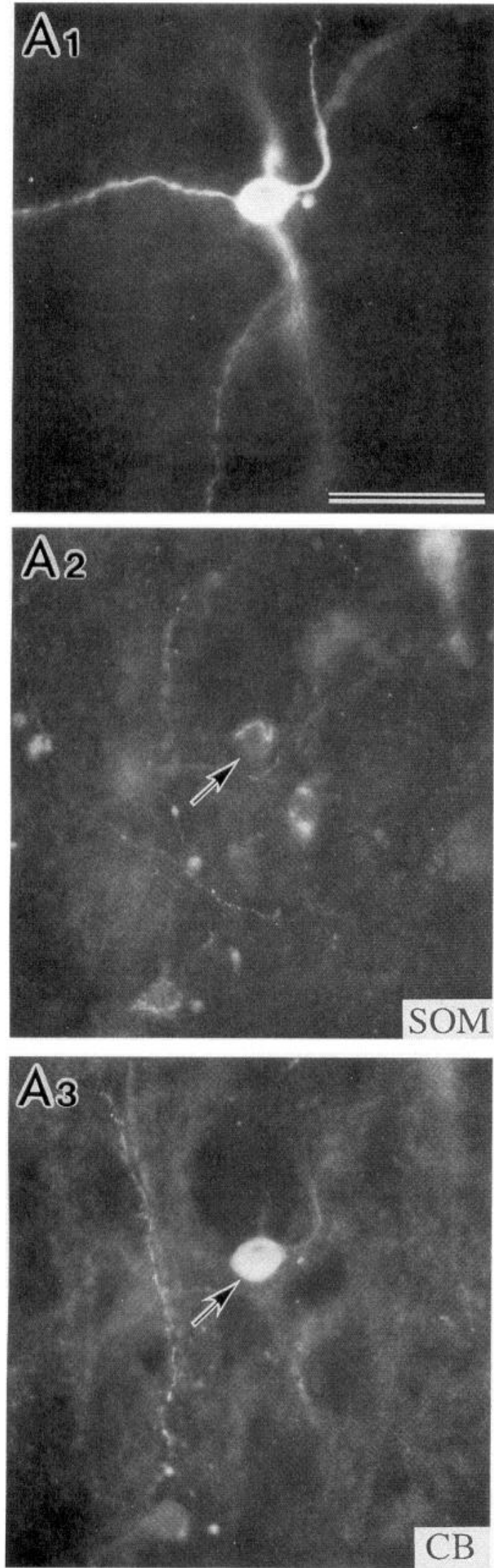

\section{$\mathrm{CR}(+), \operatorname{SOM}(-)$}

\section{$\mathrm{CB}(+), \mathrm{SOM}(+)$}

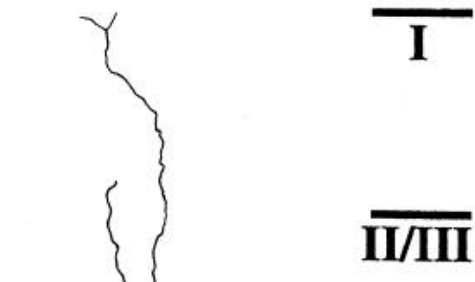

Figure 6. Calbindin $\mathrm{D}_{28 \mathrm{k}}$ and calretinin immunoreactivity in nonpyramidal cells with vertical axonal arbors. $A$, Triple photomicrographs from the same microscopic field showing a physiologically identified biocytin-filled cell $(A 1)$ was positive both for somatostatin $(S O M)(A 2)$ and for calbindin $\mathrm{D}_{28 \mathrm{k}}(C B)$ $(A 3)$ in layer V. This cell belonged to BSNP cells with ascending axonal arbors. Scale bar, $50 \mu \mathrm{m}$. B, A calbindin $\mathrm{D}_{28 \mathrm{k}^{-}}$- and somatostatin-positive cell with ascending axonal arbors (Martinotti cell). This cell belonged to BSNP cells. $C$, A calretinin $(C R)$-positive but somatostatin-negative cell with descending axonal arbors (bipolar cell). This cell belonged to BSNP cells. 
iological characteristics of VIP cells and are considered to belong to a similar subgroup.

\section{GABAergic vertical axonal arbors of BSNP and RSNP cells}

The above results suggest that the neocortex contains two types of vertical axonal arbors characterized by the presence of different neuropeptides and arising from different classes of nonpyramidal cells. The vertical axonal arbors of cells physiologically identified as RSNP or BSNP cells (Fig. 7A1,B3) were investigated electron microscopically by postembedding GABA immunohistochemistry. The axonal collaterals of 3 cells with descending axonal arbors (Fig. $7 A 2$ ) and 2 cells with ascending axonal arbors (Fig. $7 \mathrm{B1}, \mathrm{B2}$ ) were all immunoreactive for GABA. Cells with descending axonal arbors made the symmetrical synapses on dendrites, and a few on somata. Cells with ascending axonal arbors made the symmetrical synapses on thin dendritic branches including spine necks. Hence, both VIP cells with descending axonal arbors and somatostatin cells with ascending axonal arbors may include GABAergic nonpyramidal cells with symmetrical synapses on other neocortical cells.

\section{GABAergic axonal arbors of FS and LS cells negative for somatostatin and VIP}

The above results indicate that somatostatin and VIP are expressed mostly in GABAergic RSNP cells or BSNP cells, but not in FS cells or LS cells. To determine whether synapses made by FS and LS cells are also GABAergic, the axonal arbors of 5 FS cells (Fig. $8 A 1, A 3$ ) and $1 \mathrm{LS}$ cell (Fig. $8 B 1, B 3$ ) were investigated electron microscopically by postembedding GABA immunohistochemistry. Their axonal collaterals and terminals wcre all positive for GABA (Fig. 9A2, B2). FS cells made the symmetrical synapses on thick dendrites and somata including pyramidal cells. The dendrites innervated by FS cells seemed thicker than those innervated by other types of nonpyramidal cells. Half of the synapses by FS cells were on the transition area from the dendritic shaft to the neck of spines. An LS cell made symmetrical synapses on dendrites, and rarely on somata.

\section{DISCUSSION}

\section{Physiological classification of nonpyramidal cells}

Four broad classes of nonpyramidal cells were identified in previous papers (Kawaguchi, 1993, 1995). They are the FS, LS, LTS, and RSNP cells. In these classifications, nonpyramidal cells with short-duration depolarizing humps from hyperpolarized potentials are grouped with the RSNP cells (Kawaguchi, 1995). Some of these cells produced two spikes on the humps (Fig. 3C2). In this paper, these cells as well as cells with prominent LTS (Fig. 2C2) have been classified into "burst-spiking nonpyramidal (BSNP)" cells. Identifying nonpyramidal cell subtypes was more convenient experimentally. Under these classifications of nonpyramidal cells, we have found that most somatostatin or VIP cells belong to RSNP or BSNP cells, but not to FS or LS cells.

This study was carried out on tissue from juvenile rats $(18-22 \mathrm{~d}$ old). Neocortical pyramidal cells in juvenile rats (11-16 d postnatal) show less negative resting potentials, higher input resistance, longer membrane time constant, and longer duration spikes than in adult rats (28-41 d postnatal) (Luhmann and Prince, 1991). Extensive postnatal changes occur in rat medial prefrontal cortex in the numbers and appearance of GABA-containing cells (Vincent et al., 1995), suggesting that physiological, immunohisto- chemical, and morphological characteristics may also be an unknown variable in adult rats.

\section{Burst-firing heterogeneity among somatostatin and VIP cells}

Among the nonpyramidal cells immunoreactive for somatostatin or VIP, correlations of firing patterns with the other characteristics were more variable than neuropeptide phenotype with axonal arborization pattern. Both somatostatin cells and VIP cells include BSNP cells and RSNP cells, although BSNP cells with prominent LTS were mainly layer V somatostatin cells. All-ornone bursts of regular spikes are influenced by the concentration of intracellular calcium in pyramidal cells (Friedman and Gutnick, 1989) and by extracellular potassium concentration (Jensen et al., 1994). In the same class of pyramidal cclls, for example, the corticospinal cells, some show bursts but others do not (Tseng and Prince, 1993). Therefore, burst firing of spikes in somatostatin cells and VIP cells may be heterogeneous even within the same class.

\section{Defined subgroups of diverse GABAergic nonpyramidal cells}

Characterization in terms of firing patterns, immunoreactivity for somatostatin, VIP, and parvalbumin, and axonal arborization patterns suggests identifying four groups (I-IV) of nonpyramidal cells in neocortex. Each group may include nonpyramidal cells with axon terminals immunoreactive for GABA and making symmetrical synapses on other cortical cells.

(I) The first group is the parvalbumin FS cells with lower input resistances and spikes of short duration. These cells show abrupt episodes of nonadapting repetitive discharges. Parvalbumin FS cells are considered to produce GABAergic IPSPs (Huettner and Baughman, 1988; Thomson et al., 1993). This group is considered to include morphologically extended plexus cells (Fairén et al., 1984; DeFelipe, 1993) the axonal plexuses of which are local in nature, but not as compact as neurogliaform cells, exceeding the limits of the dendritic fields (Kawaguchi, 1993; Kawaguchi, 1995). A few branches of some parvalbumin FS cells make multiple boutons on the perikarya (Kawaguchi and Kubota, 1993; Kawaguchi, 1995).

(II) The second group is somatostatin cells (Hendry et al., 1984a; De Lima and Morrison, 1989), which include both RSNP and BSNP cells. Some somatostatin BSNP cells in layer V exhibit prominent LTS. Somatostatin cells morphologically include cells with main ascending axons to layer I and with more ascending collaterals than descending and horizontal ones. This group includes Martinotti cells in deep layers (Fairén et al., 1984). Layer V RSNP and BSNP cells containing somatostatin are also positive for calbindin $D_{28 k}$, although calbindin $D_{28 k}$ is also expressed both in pyramidal cells and nonpyramidal cells immunoreactive for parvalbumin in layer II/III (Rogers, 1992; Kubota et al., 1994). This subgroup includes cells immunoreactive for neuropeptide $Y$ (Hendry et al., 1984a; Rogers, 1992) or nitric oxide synthase (Kubota et al., 1994).

(III) The third group is VIP cells (Connor and Peters, 1984; Peters et al., 1987), which also include both RSNP and BSNP cells. VIP cells include three morphological types. One type is cells with long descending main axons and more descending collaterals. These morphologically include bipolar cells (Peters, 1984) and double bouquet cells (Somogyi and Cowey, 1984). Another type of VIP cell is the small basket cell (Fairén et al., 1984) the axonal branches of which make multiple contacts pref- 


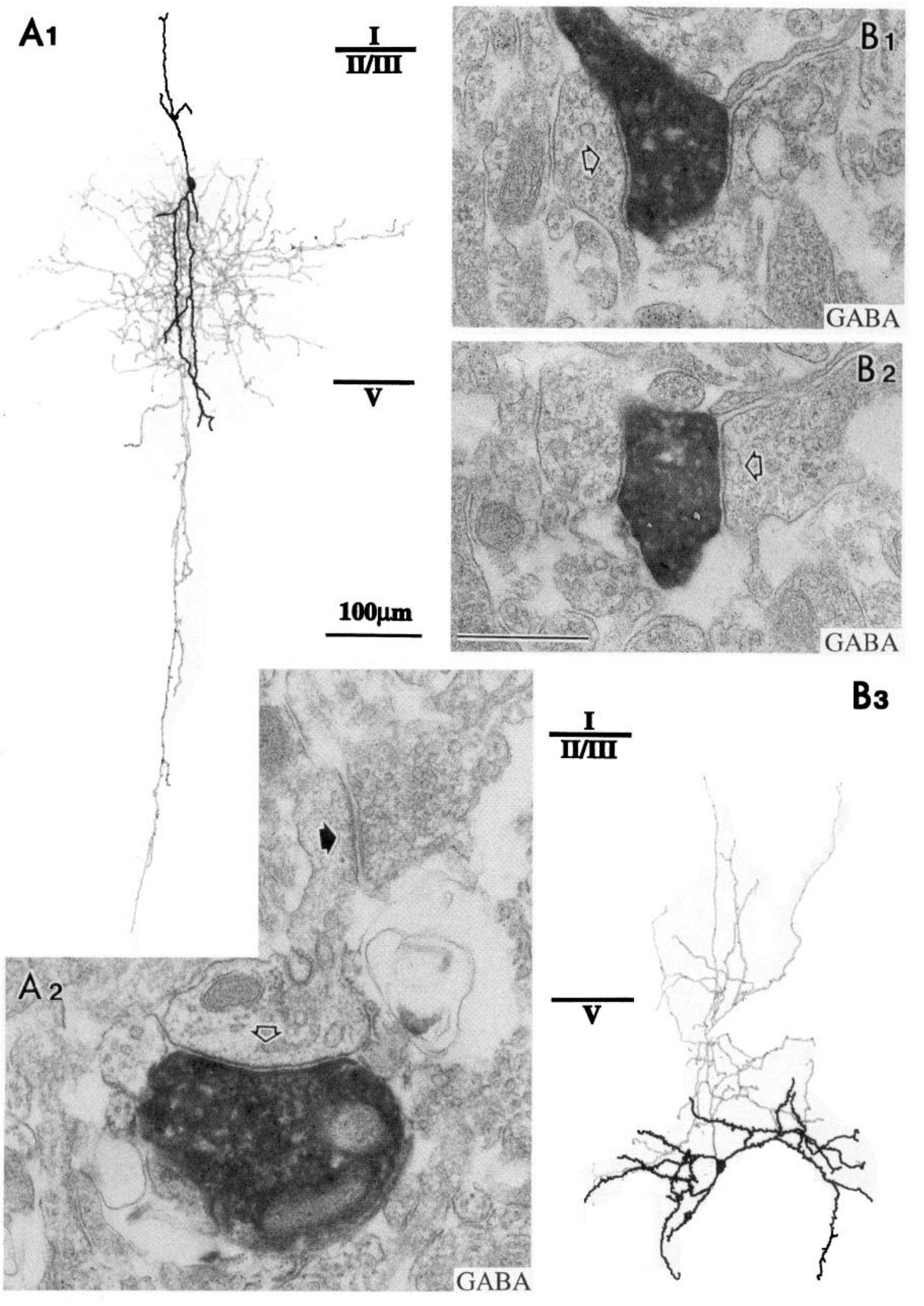

Figure 7. GABA-immunoreactive terminals of vertical axonal arbors. $A$, An RSNP cell with descending axons in layer II/III. $A 1$, This was a bipolar cell in layer II/III. A2, The axon terminal of the RSNP cell with descending axon collaterals is GABA-immunopositive as demonstrated by colloidal gold particles $(5 \mathrm{~nm})$. It makes symmetrical synaptic contact with a dendrite (open arrow), which receives asymmetrical synapse with a GABA-negative terminal (black arrow). B, A BSNP cell with ascending axons in layer V. B1, B2, The axon terminal of the BSNP cell with ascending axons is GABA-immunopositive as demonstrated by colloidal gold particles. It makes symmetrical synaptic contact with a thin dendritic branch in serial sections (open arrow). Scale bar, $1 \mu \mathrm{m}$. B3, This was a Martinotti cell in layer V. 

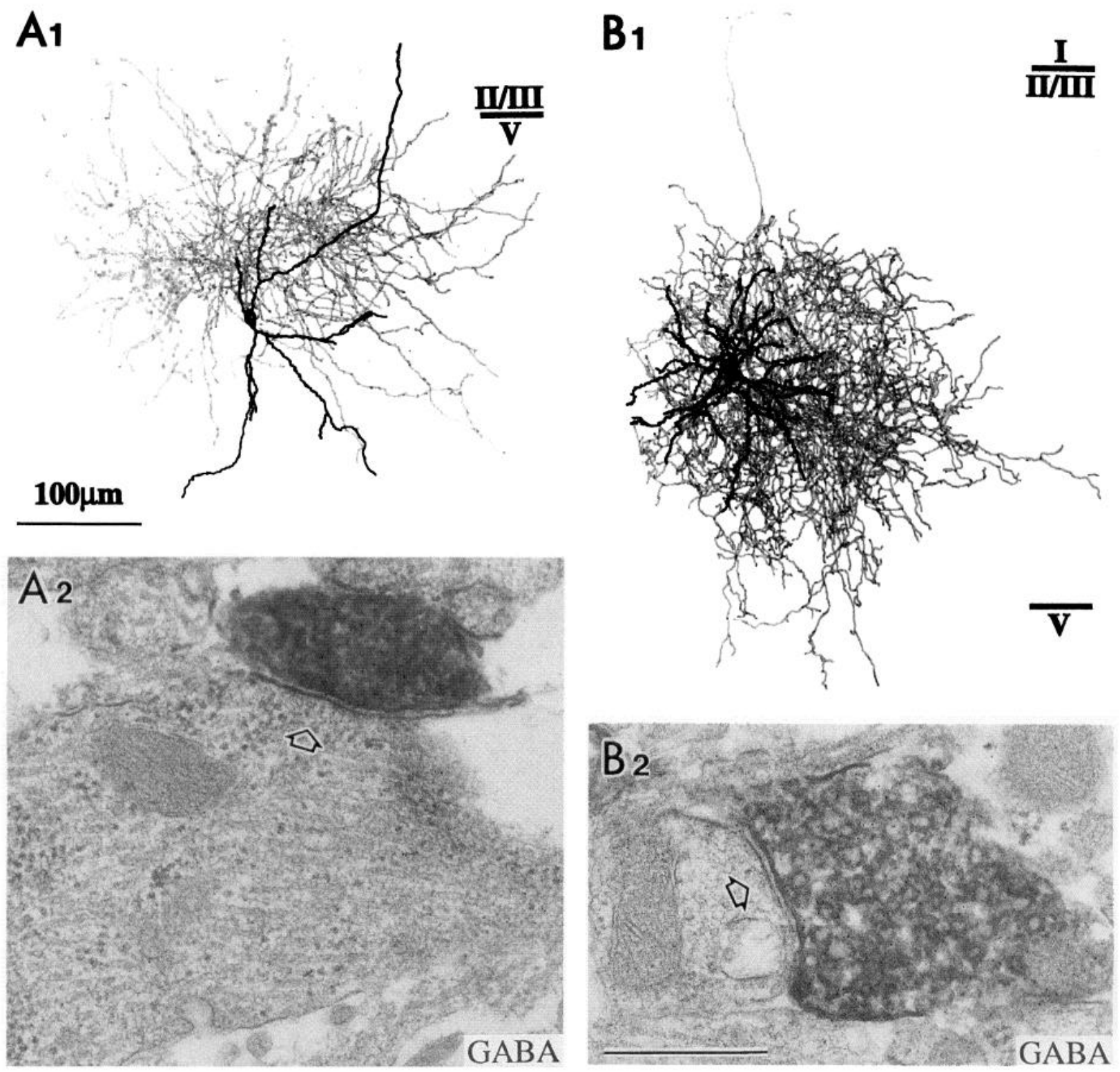

A3

B3
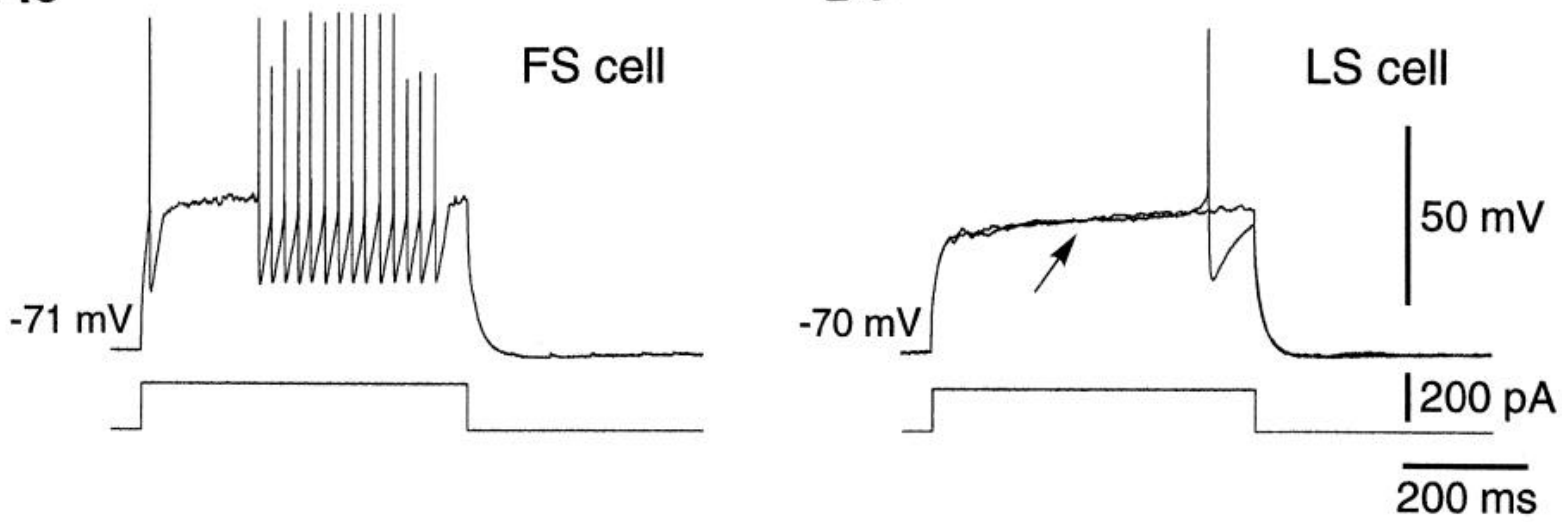

Figure 8. GABA-immunoreactive axonal terminals of an FS cell and an LS cell. A, A layer V FS cell. A1, This cell had a dense local plexus above the level of the cell body (extended plexus cell). A2, The axon terminal of the FS cell is immunopositive for GABA as demonstrated by dense colloidal gold particles $(5 \mathrm{~nm}$ ). It makes symmetrical synaptic contact with a dendritic shaft (open arrow). A3, The spike discharges of the FS cell induced by a current pulse of a threshold stimulus. Note the abrupt start of nonadaptive firings. Increasing stimulus intensity induced continuous, nonadapting, repetitive discharges during current pulses (not shown). B, An $L S$ cell in layer II/III. B1, This was a neurogliaform cell. B2, The axon terminal of the LS cell is immunopositive for GABA as demonstrated by dense colloidal gold particles. It makes symmetrical synaptic contact with the dendrite (open arrow). Scale bar, $1 \mu \mathrm{m}$. B3, The voltage responses of the LS cell induced by current pulses. Note the slowly developing ramp depolarization (arrow). 
erentially on cell bodies and proximal dendrites. The other type is arcade cells forming axonal arcades. Some calretinin cells may also belong to VIP cells (Rogers, 1992; Lund and Lewis, 1993; Kubota et al., 1994).

(IV) The fourth group includes LS cells exhibiting slowly developing ramp depolarization. Immunoreactivity for somatostatin, VIP, or parvalbumin (Kawaguchi, 1995) has not been detected in LS cells that include neurogliaform cell the axon of which, soon after its origin, breaks up into a very dense, highly ramified arborization composed of delicate, beaded, intertwined branches (Jones, 1984; Kawaguchi, 1995).

These results suggest that parvalbumin FS cells, somatostatin RSNP (or BSNP) cells, and VIP RSNP (or BSNP) cells are separate populations, that these three chemical markers may not be expressed in LS cells, and that parvalbumin, somatostatin, and VIP are useful markers for the physiological and morphological distinction of neocortical G $\wedge \mathrm{B} \wedge$ ergic cells.

Both somatostatin cells and VIP cells included RSNP and BSNP types. There were a few VIP FS cells with spikes of short duration and abrupt repetitive firing, although their input resistances were higher than those of parvalbumin FS cells. These results suggest that intrinsic firing properties are strongly, but not completely, correlated with intracortical innervation patterns and chemical characteristics. The nonpyramidal cell types described above will be subject to subcategorization or new types will be added as nonpyramidal cells are more thoroughly investigated.

\section{Descending and ascending GABAergic and peptidergic fibers in neocortex}

Nonpyramidal cells, mainly with descending fibers, synthesize VIP and GABA, whereas cells with ascending fibers have somatostatin and GABA. Somatostatin and VIP receptors are expressed in neocortical cells (Ishihara et al., 1992; Reisine and Bell, 1995), and it has been reported that the excitability of cortical cells is cnhanced by VIP (Pawclzik ct al., 1992; Haas and Gähwiler, 1992) and is depressed by somatostatin (Wang et al., 1989; Schweizer et al., 1993). Thus, the two peptides appear to have opposite effects on neocortical cells. GABAergic cells are considered to have roles in shaping the stimulus response properties of neocortical cells in sensory areas and other areas (Jones, 1993). Because functionally related cells are often grouped vertically in neocortex, called columns (Mountcastle, 1995), vertically innervating GABAergic cells may be important for producing a functional column. Because the horizontal spread of axon collaterals may differ between vertically innervating somatostatin and VIP cells, these two types of cells may be involved in the formation of functional columns in different ways.

The present results suggest that VIP cells are BSNP and RSNP cells with descending GABAergic axonal arbors, and include double bouquet cells and bipolar cells. The target neurons in the neocortex have GABA receptors that mediate fast bicucullinesensitive IPSPs $\left(\mathrm{GABA}_{\mathrm{A}}\right)$ and slow bicuculline-insensitive IPSPs $\left(\mathrm{G} \wedge \mathrm{B} \Lambda_{\mathrm{B}}\right.$ ) (Connors et al., 1988; McCormick, 1989; Kawaguchi, 1992). These two types of IPSPs are separately induced by stimulation at particular locations and are considered to be mediated by distinct classes of inhibitory neurons (Benardo, 1994; Kang et al., 1994). Slow GABA $_{B}$ IPSPs are mainly induced by the stimulation of horizontally restricted sites in superficial layers or regions ventral to the recording site. Thus, VIP-containing double bouquet cells and bipolar cells would be candidates for the pathways producing GABA $_{B}$ IPSPs in pyramidal cells.

\section{Conclusions}

The present results suggest correlations among firing pattern, chemical phenotype, and innervation pattern of GABAergic cells in the neocortex. The pattern of vertical innervation is especially well correlated with the presence of somatostatin or VIP. These peptide-containing cell subtypes connecting layers vertically may affect neocortical local circuits through GABAergic inhibitory mechianisms that act differentially through distinctive spatial innervation patterns, temporal firing patterns, and corelease of neuropeptides.

Although the number of nonpyramidal cells studied so far is very small compared with the total population, our results indicate that these GABAergic cells may be classified by a limited number of criteria. Such a system of characterization will hopefully contribute to an understanding of the fundamental organization of the neocortex.

\section{REFERENCES}

Agmon A, Connors BW (1989) Repetitive burst-firing neurons in the deep layers of mouse somatosensory cortex. Neurosci Lett 99:137-141.

Benardo LS (1994) Separate activation of fast and slow inhibitory postsynaptic potentials in rat neocortex in vitro. J Physiol (Lond) 476:203-215.

Buhl EH, Halasy K, Somogyi P (1994) Diverse sources of hippocampal unitary inhibitory postsynaptic potentials and the number of synaptic release sites. Nature 368:823-828.

Celio MR (1986) Parvalbumin in most gamma-aminobutyric acidcontaining neurons of the rat cerebral cortex. Science 231:995-997.

Connor JR, Peters A (1984) Vasoactive intestinal polypeptide-immunoreactive neurons in rat visual cortex. Neuroscience 12:1027-1044.

Connors BW, Gutnick MJ (1990) Intrinsic firing patterns of diverse neocortical neurons. Trends Neurosci 13:99-104.

Connors BW, Malenka RC, Silva LR (1988) Two inhibitory postsynaptic potentials, and $\mathrm{GABA}_{\mathrm{A}}$ and $\mathrm{GABA}_{\mathrm{B}}$ receptor-mediated responses in neocortex of rat and cat. J Physiol (Lond) 406:443-468.

De Lima AD, Morrison JH (1989) Ultrastructural analysis of somatostatin-immunoreactive neurons and synapses in the temporal and occipital cortex of the macaque monkey. J Comp Neurol 283:212-227.

DeFelipe J (1993) Neocortical neuronal diversity: chemical heterogeneity revealed by colocalization studies of classic neurotransmitters, neuropeptides, calcium-binding proteins, and cell surface molecules. Cereb Cortex 3:273-289.

DeFelipe J, Hendry SHC, Hashikawa T, Molinari M, Jones EG (1990) A microcolumnar structure of monkey cerebral cortex revealed by immunocytochemical studies of double houquet cell axons. Neuroscience 37:655-673.

Demeulemeester H, Vandesande F, Orban GA, Brandon C, Vanderhaeghen JJ (1988) Heterogeneity of GABAcrgic cells in cat visual cortex. J Neurosci 8:988-1000.

Demeulemeester H, Vandesande F, Orban GA, Heizmann CW, Pochet R (1989) Calbindin D-28K and parvalbumin immunoreactivity is confined to two separate neuronal subpopulations in the cat visual cortex, whereas partial coexistence is shown in the dorsal geniculate nucleus. Neurosci Lett 99:6-11.

Deuchars J, Thomson AM (1995) Single axon fast inhibitory postsynaptic potentials elicited by sparsely spiny interneurons in rat neocortex. Neuroscience 65:935-942.

Fairén A, DeFelipe J, Regidor J (1984) Nonpyramidal neurons: general account. In: Cerebral cortex, Vol 1, Cellular components of the cerebral cortex (Peters A, Jones EG, eds), pp 201-253. New York: Plenum.

Foehring RC, Lorenzon NM, Herron P, Wilson CJ (1991) Correlation of physiologically and morphologically identified neuronal types in human association cortex in vitro. J Neurophysiol 66:1825-1837.

Friedman A, Gutnick MJ (1989) Intracellular calcium and control of burst generation in neurons of guinea-pig neocortex in vitro. Eur $\mathbf{J}$ Neurosci 4:374-381.

Haas HL, Gähwiler BH (1992) Vasoactive intestinal polypeptide modulates neuronal excitability in hippocampal slices of the rat. Neuroscience $47: 273-277$. 
Hajós F, Zilles K, Gallatz K, Schleicher A, Kaplan I, Werner L (1988a) Ramification of vasoactive intestinal polypeptide (VIP)-cells in the rat visual cortex. Anat Embryol (Berl) 178:197-206.

Hajós F, Zilles K, Gallatz K, Schleicher A, Kálmán M (1988b) Types and spatial distribution of vasoactive intestinal polypeptide (VIP)containing synapses in the rat visual cortex. Anat Embryol (Berl) 178:207-217.

Hendry SHC, Jones EG, Emson PC (1984a) Morphology, distribution, and synaptic relations of somatostatin- and neuropeptide Y-immunoreactive neurons in rat and monkey neocortex. J Neurosci 4:2497-2517.

Hendry SHC, Jones EG, DeFelipe J, Schmechel D, Brandon C, Emson PC (1984b) Neuropeptide containing neurons of the cerebral cortex are also GABAergic. Proc Natl Acad Sci USA 81:6526-6530.

Hendry SHC, Jones EG, Emson PC, Lawson DEM, Heizmann CW, Streit P (1989) Two classes of cortical GABA neurons defined by differential calcium binding protein immunoreactivities. Exp Brain Res 76:467-472.

Huettner JE, Baughman RW (1988) The pharmacology of synapses formed by identified corticocollicular neurons in primary cultures of rat visual cortex. J Neurosci 8:160-175.

Ishihara T, Shigemoto R, Mori K, Takahashi K, Nagata S (1992) Functional expression and tissue distribution of a novel receptor for vasoactive intestinal polypeptide. Neuron 8:811-819.

Jensen MS, Azouz R, Yaari Y (1994) Variant firing patterns in rat hippocampal pyramidal cells modulated by extracellular potassium. $\mathbf{J}$ Neurophysiol 71:831-839.

Jones EG (1975) Varieties and distribution of non-pyramidal cells in the somatic sensory cortex of the squirrel monkey. J Comp Neurol $160: 205-268$

Jones EG (1984) Neurogliaform or spiderweb cells. In: Cerebral cortex, Vol 1, Cellular components of the cerebral cortex (Peters A, Jones EG, eds), pp 409-418. New York: Plenum.

Jones EG (1993) GABAergic neurons and their role in cortical plasticity in primates. Cereb Cortex 3:361-372.

Kang Y, Kaneko T, Ohishi H, Endo K, Araki T (1994) Spatio-temporally differential inhibition of pyramidal cells in the cat motor cortex. J Neurophysiol 71:280-293.

Kawaguchi Y (1992) Receptor subtypes involved in callosally-induced postsynaptic potentials in rat frontal agranular cortex in vitro. Exp Brain Res 88:33-40.

Kawaguchi Y (1993) Groupings of nonpyramidal and pyramidal cells with specific physiological and morphological characteristics in rat frontal cortex. J Neurophysiol 69:416-431.

Kawaguchi Y (1995) Physiological subgroups of nonpyramidal cells with specific morphological characteristics in layer II/III of rat frontal cortex. J Neurosci 15:2638-2655.

Kawaguchi Y, Kubota Y (1993) Correlation of physiological subgroupings of nonpyramidal cells with parvalbumin- and calbindin D28kimmunoreactive neurons in layer $\mathrm{V}$ of rat frontal cortex. J Neurophysiol 70:387-396.

Kawaguchi Y, Kubota Y (1995) Local circuit neurons in the frontal cortex and the neostriatum. In: Functions of cortico-basal ganglia loop (Kimura M, Graybiel AM, eds), pp 73-88. Tokyo: Springer.

Kubota Y, Kawaguchi Y (1994) Three classes of GABAergic interneurons in neocortex and neostriatum. Jpn J Physiol 44:S145-S148.

Kubota Y, Hattori R, Yui Y (1994) Three distinct subpopulations of GABAergic neurons in rat frontal agranular cortex. Brain Res 649:159-173

Luhmann HJ, Prince DA (1991) Postnatal maturation of the GABAergic system in rat neocortex. J Neurophysiol 65:247-263.

Lund JS, Lewis DA (1993) Local circuit neurons of developing and mature macaque prefrontal cortex: Golgi and immunohistochemical characteristics. J Comp Neurol 328:282-312.

Mason A, Larkman A (1990) Correlations between morphology and electrophysiology of pyramidal neurons in slices of rat visual cortex. II. Electrophysiology. J Neurosci 10:1415-1428.

McCormick DA (1989) GABA as an inhibitory neurotransmitter in human cerebral cortex. J Neurophysiol 62:1018-1027.
McCormick DA, Connors BW, Lighthall JW, Prince DA (1985) Comparative electrophysiology of pyramidal and sparsely spiny stellate neurons of the neocortex. J Neurophysiol 54:782-806.

Mizukawa K, McGeer PL, Vincent SR, McGeer EG (1987) The distribution of somatostatin-immunoreactive neurons and fibers in the rat cerebral cortex: light and electronmicroscopic studies. Brain Res 426:28-36.

Mountcastle V (1995) The evolution of ideas concerning the function of the neocortex. Cereb Cortex 5:289-295.

Pawelzik H, Dodt HU, Zieglgansberger W (1992) Actions of vasoactive intestinal polypeptide (VIP) on neocortical neurons of the rat in vitro. Neurosci Lett 147:167-170.

Peters A (1984) Bipolar cells. In: Cerebral cortex, Vol 1, Cellular components of the cerebral cortex (Peters A, Jones EG, eds), pp 381-407. New York: Plenum Press.

Peters A (1990) The axon terminals of vasoactive intestinal polypeptide (VIP)-containing bipolar cells in rat visual cortex. J Neurocytol 19:672-685.

Peters A, Saint Marie RL (1984) Smooth and sparsely spinous nonpyramidal cells forming local axonal plexuses. In: Cerebral cortex, Vol 1 , Cellular components of the cerebral cortex (Peters A, Jones EG, eds), pp 419-445. New York: Plenum.

Peters A, Meinecke DL, Karamandilis AN (1987) Vasoactive intestinal polypeptide immunoreactive neurons in the primary visual cortex of the rat. J Neurocytol 16:23-38.

Phend KD, Weinberg RJ, Rustioni A (1992) Techniques to optimize post-embedding single and double staining for amino acid neurotransmitters. J Histochem Cytochem 40:1011-1020.

Ramón y Cajal S (1995) Histology of the nervous system, Vol 2 (Swanson N, Swanson LW, translators). New York: Oxford UP.

Reisine T, Bell GI (1995) Molecular properties of somatostatin recep tors. Neuroscience 67:777-790.

Rogers JH (1992) Immunohistochemical markers in rat cortex: colocalization of calretinin and calbindin-D28k with neuropeptides and GABA. Brain Res 587:147-157.

Schweizer P, Madamba S, Champagnat J, Siggins GR (1993) Somatostatin inhibition of hippocampal CA1 pyramidal neurons: mediation by arachidonic acid and its metabolites. J Neurosci 13:2033-2049.

Somogyi P (1989) Synaptic organization of GABAergic neurons and $\mathrm{GABA}_{\mathrm{A}}$ receptors in the lateral geniculate nucleus and visual cortex. In: Neural mechanisms of visual perception (Lam DK-T, Gilbert CD, eds), pp 35-62. Woodlands, TX: Portfolio.

Somogyi P, Cowey A (1984) Double bouquet cells. In: Cerebral cortex, Vol 1, Cellular components of the cerebral cortex (Peters A, Jones EG eds), pp 337-360. New York: Plenum.

Somogyi P, Hodgson AJ, Smith AD, Nunzi MG, Gorio A, Wu J-Y (1984) Different populations of GABAergic neurons in the visual cortex and hippocampus of cat contain somatostatin- or cholecystokininimmunoreactive material. J Neurosci 4:2590-2603.

Thomson AM, Deuchars J, West DC (1993) Single axon excitatory postsynaptic potentials in neocortical interneurons exhibit pronounced paired pulse facilitation. Neuroscience 54:347-360.

Tseng G-F, Prince DA (1993) Heterogeneity of rat corticospinal neurons. J Comp Neurol 335:92-108.

Valverde F (1978) The organization of area 18 in the monkey: Golgi study. Anat Embryol (Berl) 154:305-334.

Vincent SL, Pabreza L, Benes FM (1995) Postnatal maturation of GABA-immunoreactive neurons of rat medial frontal cortex. J Comp Neurol 355:81-92.

Wahle P (1993) Differential regulation of substance $P$ and somatostatin in Martinotti cells of the developing cat visual cortex. J Comp Neurol 329:519-538.

Wang HL, Bogen C, Reisine T, Dichter M (1989) Somatostatin-14 and somatostatin-28 induce opposite effects on potassium currents in rat neocortical neurons. Proc Natl Acad Sci USA 86:9616-9620.

White EL (1989) Cortical circuits: synaptic organization of the cerebral cortex structure, function, and theory (White EL, Keller A, eds), Boston: Birkhäuser. 